DOI: 10.17707/AgricultForest.63.3.01

\author{
Ivan ŠIMUNIĆ, Palma ORLOVIĆ-LEKO, Ankica SENTA MARIĆ, \\ Irena CIGLENEČKI, Tatiana MINKINA, Vilim FILIPOVIĆ
}

\title{
QUALITY OF SURFACE WATER IN THE AGRICULTURAL DISTRICT LONJA FIELD (CROATIA)
}

\begin{abstract}
SUMMARY
The objective of this study was to estimate the impact of land use on the surface water quality. Water samples were collected in the main drainage channel, in the agricultural area of Lonja field, Croatia. Lonja field is the largest protected wetland in both Croatia and the entire Danube basin. It extends along the river Sava and the lower course of the river Lonja. Sampling was performed during the spring months in 2015, 2016 and 2017. Investigation was done through the measurements of physicochemical indicators: $\mathrm{pH}$ value, biochemical oxygen demand (BOD), concentration of oxygen, nitrate, phosphate, trace metals ( $\mathrm{Zn}, \mathrm{Pb}$ and $\mathrm{Cd}$ ), dissolved organic carbon (DOC), and surface active fraction of DOC. The obtained results were compared with those of the Lonja and Sava rivers. The significant higher concentrations of DOC (up to about $13 \mathrm{mg} \mathrm{C} \mathrm{dm}{ }^{-3}$ ) have been observed in the water from main drainage channel. It is known that, high DOC concentrations in surface waters have negative effects on the water quality and water habitats.
\end{abstract}

Keywords: surface water quality, agricultural area, physicochemical indicators, dissolved organic matter.

\section{INTRODUCTION}

Water quality for a particular purpose is determined on the basis of indicators of the composition, properties and concentration of individual substances in water (Šimunić, 2016).

In various soil-plant systems, pollutants may constitute a potential risk to the environment through their uptake by plants and subsequent input the food chain and, and the danger ensuing from their tendency to accumulate in vital organs of human, animals and plants, or because of possible contamination of drinking water.

\footnotetext{
${ }^{1}$ Ivan Šimunić, (corresponding author: simunic@agr.hr) Vilim Filipović, University of Zagreb, Faculty of Agriculture, Department of Soil Amelioration, Zagreb, CROATIA, Palma Orlović-Leko University of Zagreb, Faculty of Mining, Geology and Petrology Engineering, Zagreb, CROATIA, Ankica Senta Marić University of Zagreb, Medical Faculty, School of Public Health "Andrija Štampar", Zagreb, CROATIA, Irena Ciglenečki Divisin of Marine and Environmental Reasearch, Ruđer Bošković Institute, Zagreb, CROATIA, Tatiana Minkina Southern Federal University, Soil Science and Agrochemistry Department, Rostov-on-Don, RUSSIA.

Presented at the $7^{\text {th }}$ International Symposium of Ecologists (ISEM7), Sutomore, Montenegro.

Notes: The authors declare that they have no conflicts of interest. Authorship Form signed online.
} 
Excessive nitrate and phosphorus concentration in water may lead to eutrophication of watercourses or stock watering places. If such water is used for human consumption, it may cause methemoglobinemia in infants and animals (Pratt and Jury, 1984; Matson et al., 1997). Potencial cancer risk from nitrate and nitrite in water and food has been reported Rademacher et al. (1992). Leaching of nitrates from soil depends on many factors, such as amount, frequency and intensitety of precipitation, soil properties, crop type and it's development, evaporation, soil tillage and nitrogen fertilization (Vidaček et al., 1999; Nemeth, 2006; Josipović et al., 2006; Nemčić et al., 2007; Šimunić at al., 2011). The problem of nitrate (and other pollutants) leaching is even pronounced in agrecosystems of hydroameliorated fields, especially in drained soils because of changed infiltration and filtration capabilities of these soils.

One of the parameters in evaluation criteria of the natural waters ecological status is trace metals concentrations (Water Framework Directive, 2000). Metals may include non-essential ones, such as $\mathrm{Cd}$ and $\mathrm{Pb}$ that can be toxic even at trace levels, and biologically essential elements, such as $\mathrm{Cu}, \mathrm{Fe}, \mathrm{Mn}$ and $\mathrm{Zn}$, which might cause toxic effects at elevated concentrations (Wong et al., 2006; Jakovčić at al., 2003). The essential heavy metals exert biochemical and physiological functions in plants and animals. Metals are non-biodegradable and accumulative in nature (Tchounwou et al., 2012). Although the speciation of metals is important because has a profound effect on their biological availability, the total/dissolved concentration gives a general overview of the particular water body (Cukrov et al., 2008).

Dissolved organic matter (DOM), one of the most complex naturally occurring mixtures, plays a central role in the biogeochemistry and the photochemistry of natural waters. Dissolved organic carbon (DOC) is the measurable elemental organic carbon content of DOM

(Filella, 2009) and is generally defined as compounds that can pass through a $0.45 \mu \mathrm{m}$ or $0.7 \mu \mathrm{m}$ filter. DOC provides a nutritional and energy base for life i.e. micro-and macro-organisms, and is a source for nutrient regeneration, ion exchange capacity, light and heat absorption, having major impact on the speciation of many trace elements. However, high DOC concentrations in surface waters have negative effects on the water quality and water habitats. Further, in the biogeochemical processes in aquatic environment, the physicochemical properties of organic matter are often more important than the amount present. The fraction of DOC which possesses surface active properties may be very important for natural freshwater. The molecules of surface active substances (SAS) have their hydrophilic parts oriented towards the water phase while the hydrophobic ends are located on the air, which is a thermodynamically favourable configuration. Organic SAS are concentrated by adsorption processes on natural phase boundaries: water-atmosphere, water-sediment, watersuspended particles, where they greatly affect transfer of mass and energy (Ćosović and Vojvodić, 1998). Research on the DOC and SAS provides an important tool for better understanding of the content, distribution, physico- 
chemical characteristics as well as dynamics of the complex mixture of DOM in the natural waters (Orlović-Leko et al., 2016).

The objective of this study was to estimate the impact of the use of hydromeliorated agricultural land for cultivation of agricultural crops on the surface water quality.

\section{MATERIAL AND METHODS}

Hydroameliorated agricultural land is located in the central part of the river Sava valley and partially borders the Lonja field Nature Park, which is the largest protected wetland both in Croatia and the entire Danube basin. It extends along the river Sava and the lower course of the river Lonja. Total area of the hydroameliorated land is about 4.000 ha.

Water samples were collected in the main drainage channel and rivers Sava and Lonja. Sampling was performed during the spring months in 2015, 2016 and 2017. Investigation was done through the measurements of physicochemical and chemical indicators: $\mathrm{pH}$ value, biochemical oxygen demand (BOD), concentration of oxygen, nitrate, phosphate, trace metals ( $\mathrm{Zn}, \mathrm{Pb}$ and $\mathrm{Cd}$ ), dissolved organic carbon (DOC), and surface active fraction of DOC.

- $\mathrm{pH}$ value was measured by pH meter-HRN ISO 10523:2012.

- Electrical conductivity is determined by norm HRN EN 27888:2008.

- Biochemical oxygen demand by norm HRN ISO 5815:1998 en.

- Concentration of oxygen by HRN EN 25813:1998 en.

- Nitrate was determined by spectrophotometrically method-HRN ISO 13395:1996.

- Phosphorus was determined by method continous flow analysis-HRN ISO 15681-2:2008.

- Trace elements were determined by AAS- HRN ISO 8288:1998 (ISO 8288:1986).

- Dissolved organic carbon (DOC) concentrations were determined by using a high-temperature

- Catalytic oxidation analyzer (TOC-5000 Model, Shimadzu, Japan).

- Surface active substances (SAS) were measured by the electrochemical method (AC voltammetry, out of phase). For the quantification of the SAS content in samples a calibration plot of the nonionic surfactant Triton-X-100 was used (Ćosović and Vojvodić, 1998; Orlović-Leko et al., 2016).

- The quality of the surface waters is determined on the basis of the Water Classification Decree (National Gazette, 137/08).

\section{RESULTS}

Water quality is determined by a number of indicators that can be divided into pyisicochemical, oxygen regime indicators, nutrients and biological indicators.

Results of investigation are presented in Tables 1 - 5. Pysicochemical indicators are presented through $\mathrm{pH}$ value, electrical conductivity (EC) (Table 1). 
Oxygen regime indicators are presented through concentration of oxygen and biochemical oxygen demand (Table 2). Nutrients through nitrates, ammonia and phosphorus (Table 3). Trace metals ( $\mathrm{Zn}, \mathrm{Pb}$ and $\mathrm{Cd}$ ) are listed in Table 4. Additionally, organic matter is investigated through the study of surface activity (SA) of dissolved organic carbon (DOC), Table 5 and the ratio SAS/DOC values (Table 6).

\section{Pysicochemical indicators}

\section{DISCUSSION}

Value of $\mathrm{pH}$ is an important indicator of water quality. If the $\mathrm{pH}$ values of water are in the range between $\mathrm{pH}=6.5$ and $\mathrm{pH}=8.5$, it means that water can be used for all purposes. If the $\mathrm{pH}$ value falls between $\mathrm{pH}=6.0$ and $\mathrm{pH}=6.5$ than water have to be purifed before for any purpose of use and outside these $\mathrm{pH}$ values, water is a undesirable environment for plants and animal world and is not recommended for use in technological purposes. In Table 1 are presented the $\mathrm{pH}$ values of the investigated water samples.

According to the $\mathrm{pH}$ values, the water were in first class and were rated as a high state. Electrical conductivity (EC) is an indicator of salt concentration in water, i.e. water salinity. Informations about salt concentration in water indicates its usability in irrigation, since a higher salt concentration can cause soil salinity, that is, higher concentration of salt in soil solutions has an adverse effect on water uptake through plant roots, which in turn causes a drop in turgor pressure. Reduced turgor leads to plant limpness, drying and falling of leaves, as well as lower yields. As most plants are sensitive to the presence of salts, it is recommended that salt concentration in irrigation water should not surpass limit value of $3 \mathrm{dS} / \mathrm{m}$ (Ayers and Westcot, 1985), or more precisely salt concentration to $0.7 \mathrm{dS} / \mathrm{m}$ there are no limitations.

Table 1: Pysicochemical indicators

\begin{tabular}{|c|c|c|c|c|c|c|}
\hline \multirow{2}{*}{ Water system } & \multicolumn{3}{|c|}{$\mathrm{pH}$} & \multicolumn{3}{c|}{$\begin{array}{c}\text { Electrical conductivity - } \\
\end{array}$} \\
\cline { 2 - 7 } & 2015 & 2016 & 2017 & 2015 & 2016 & 2017 \\
\hline Main drainage channel & 7.6 & 7.7 & 7.5 & 0.380 & 0.356 & 0.370 \\
\hline Rating for each indicator & $\mathrm{I}$ & $\mathrm{I}$ & $\mathrm{I}$ & $\mathrm{I}$ & $\mathrm{I}$ & $\mathrm{I}$ \\
\hline River Lonja & 7.7 & 7.8 & 7.8 & 0.440 & 0.439 & 0.453 \\
\hline Rating for each indicator & $\mathrm{I}$ & $\mathrm{I}$ & $\mathrm{I}$ & $\mathrm{I}$ & $\mathrm{I}$ & $\mathrm{I}$ \\
\hline River Sava & 7.7 & 7.7 & 7.7 & 0.420 & 0.442 & 0.438 \\
\hline Rating for each indicator & $\mathrm{I}$ & $\mathrm{I}$ & $\mathrm{I}$ & $\mathrm{I}$ & $\mathrm{I}$ & $\mathrm{I}$ \\
\hline
\end{tabular}

From the Table 1, it is evident that the EC in all surface water were less than $0.5 \mathrm{dS} / \mathrm{m}$ and puts water in the first class and was rated as a high state.

Based on physico-chemical indicators, surface water of all water bodies are classified into the first class and their condition is marked as high. 


\section{Oxygen regime indicators}

Organic matter in water refers to all substances that are in natural water in dissolved and suspended form. Total organic matter is divided into biologically degradable and nondegradable substances. According to its origin, organic matter in water can be a product of biochemical processes or a product of human activities. Occurrence of water pollution is a consequence of soil leaching by precipitation water as well as of components of urban and industrial westwaters. Indicator of organic matter degradability in water by microorganisms is called the biochemical oxygen demand (BOD). Total biochemical oxygen consumption is the amount of oxygen required for complete organic matter degradation (Šimunić, 2016).

As evident from Table 2, the oxygen concentration in the water channel was in the category of the third class and the water status was rated as moderately, while according to biochemical oxygen demand water channel was in the category of the second class and the water status was rated as good.

According to the indicator group, the channel water corresponds to the third category and the water status is rated as moderate.

In all years of research the oxygen concentrations in the rivers of Lonja and Sava were in the category of the first class and the water status was rated as high, while according to biochemical oxygen demand water were in the category of the third class and the water status was rated as moderate. According to the indicator group, the water of rivers Lonja and Sava are classified in the third category and the water status is rated as moderate.

Table 2: Oxygen regime indicators

\begin{tabular}{|c|c|c|c|c|c|c|c|}
\hline \multirow{2}{*}{ Water system } & \multicolumn{3}{|c|}{ Oxygen $\left(\mathrm{mg} \mathrm{O}_{2} / \mathrm{L}\right)$} & \multicolumn{3}{|c|}{$\begin{array}{c}\text { Biochemical oxygen demand- } \\
\mathrm{BOD}_{5}\left(\mathrm{mg} \mathrm{O}_{2} / \mathrm{L}\right)\end{array}$} & $\begin{array}{c}\text { Rating by } \\
\text { indicator } \\
\text { group }\end{array}$ \\
\cline { 2 - 7 } & 2015 & 2016 & 2017 & 2015 & 2016 & 2017 & \\
\hline $\begin{array}{c}\text { Main drainage } \\
\text { channel }\end{array}$ & 5.54 & 4.69 & 5.90 & 3.09 & 3.16 & 3.87 & \\
\hline $\begin{array}{c}\text { Rating for each } \\
\text { indicator }\end{array}$ & $\mathrm{III}$ & $\mathrm{III}$ & $\mathrm{III}$ & $\mathrm{II}$ & $\mathrm{II}$ & $\mathrm{II}$ & $\mathrm{III}$ \\
\hline River Lonja & 8.01 & 9.61 & 9.49 & 4.76 & 5.53 & 4.33 & \\
\hline $\begin{array}{c}\text { Rating for each } \\
\text { indicator }\end{array}$ & $\mathrm{I}$ & $\mathrm{I}$ & $\mathrm{I}$ & $\mathrm{III}$ & $\mathrm{III}$ & $\mathrm{III}$ & III \\
\hline River Sava & 8.17 & 8.32 & 8.06 & 4.82 & 5.12 & 4.12 & \\
\hline $\begin{array}{c}\text { Rating for each } \\
\text { indicator }\end{array}$ & $\mathrm{I}$ & $\mathrm{I}$ & $\mathrm{I}$ & $\mathrm{III}$ & $\mathrm{III}$ & $\mathrm{III}$ & III \\
\hline
\end{tabular}

\section{Nutrients}

Nutrients in water mostly refer to dissolved nitrogen and phosphorus compounds. Nutrients can get into water by leaching from agricultural soils where they are used as mineral fertilizers and from household and industrial wastewater. Increased concentration of nutrients in water causes intensified production of primary organic matter, namely, eutrophication, These compounds 
are found in water in different forms and are subject to changes, in dependence on the amount of oxygen in water.

In the investigated period, concentration of nitrates in main water channel was in the category of the third class and the water status was rated as moderately, while according to concentration of ammonia, it was in the category of the fifth class and the water status was rated as bad. According to the concentration of phosphorus it was in the second class and was rated as good. (Table 3). According to the indicator group, the water channel is classified into the fifth category and the water status is rated as bad.

Table 3: Nutrients

\begin{tabular}{|c|c|c|c|c|c|c|c|c|c|c|}
\hline \multirow{2}{*}{$\begin{array}{c}\text { Water } \\
\text { system }\end{array}$} & \multicolumn{3}{|c|}{$\begin{array}{c}\text { Nitrates NO3-N } \\
\text { (mg/L) }\end{array}$} & \multicolumn{3}{c|}{$\begin{array}{c}\text { Ammonia NH4-N } \\
\text { (mg/L) }\end{array}$} & \multicolumn{3}{c|}{$\begin{array}{c}\text { Phosphorus PO4-P } \\
\text { (mg/L) }\end{array}$} & $\begin{array}{c}\text { Rating by } \\
\text { indicator } \\
\text { group }\end{array}$ \\
\cline { 2 - 11 } & 2015 & 2016 & 2017 & 2015 & 2016 & 2017 & 2015 & 2016 & 2017 & \\
\hline $\begin{array}{c}\text { Main } \\
\text { drainage } \\
\text { channel }\end{array}$ & 2.52 & 3.17 & 3.43 & 3.62 & 1.55 & 2.27 & 0.15 & 0.13 & 0.16 & \\
\hline $\begin{array}{c}\text { Rating for } \\
\text { each } \\
\text { indicator }\end{array}$ & III & III & III & V & V & V & II & II & II & V \\
\hline $\begin{array}{c}\text { River } \\
\text { Lonja }\end{array}$ & 1.69 & 1.72 & 1.57 & 1.47 & 1.20 & 1.30 & 0.08 & 0.11 & 0.14 & \\
\hline $\begin{array}{c}\text { Rating for } \\
\text { each } \\
\text { indicator }\end{array}$ & III & III & III & IV & IV & IV & I & II & II & IV \\
\hline $\begin{array}{c}\text { River } \\
\text { Sava }\end{array}$ & 1.45 & 1.69 & 1.70 & 1.37 & 1.24 & 1.22 & 0.10 & 0.11 & 0.13 & \\
\hline $\begin{array}{c}\text { Rating for } \\
\text { each } \\
\text { indicator }\end{array}$ & II & III & III & IV & IV & IV & II & II & II & IV \\
\hline
\end{tabular}

Concentrations of nitrates in the rivers of Lonja and Sava were in the category of the third class and the water status was rated as moderate, while according to concentration of ammonia water were in the fourth category and the water status was rated as poor and according to the concentration of phosphorous in water, they are classified into second category. According to the indicator group, the water of rivers Lonja and Sava are classified in the fourth category and the water status is rated as poor. It is evident that the concentration of nitrates and ammonia in the water channels was higher in all years than in the Lonja and Sava river waters, which could have caused a lower oxygen concentration in the water channel, or a weaker nitrification process. The concentration of nitrates and ammonia in the rivers was similar to that of phosphorus concentrations, while the phosphorus concentration in the water channel was somewhat higher. Another reason for increased nutrient concentration in water channel is fertilization and cultivation of agricultural crops on hydromeliorated areas. Nutrient concentrations and their leaching depend on several factors, such as the amount 
of mineral fertilizer input, hydrological conditions, soil type, cultured crops and so on (Vidaček et al., 1999; Mesić et al., 2007; Šimunić et al., 2011).

\section{Trace metals}

Concentrations of trace metals ( $\mathrm{Zn}, \mathrm{Pb}$ and $\mathrm{Cd})$ in all water samples did not indicate water pollution (Table 4), which is in agreement with the results obtained by Moore (1981), Đumija et al. (1989), Čoga (1998) and Šimunić et al. (2002). Different mean concentrations of $\mathrm{Zn}$ and Cd were recorded both between years and between different aquatic bodies. The same may be assumed for $\mathrm{Pb}$ due to detection limit $(<1.0 \mu \mathrm{g} / \mathrm{L})$.

Based on concentrations of $\mathrm{Zn}$, the investigated surface water are classified into the first class and their state is marked as high. According to the concentrations $\mathrm{Pb}$ and $\mathrm{Cd}$, water are classified into the second class and their state is marked as good.

Table 4: Trace metals

\begin{tabular}{|c|c|c|c|c|c|c|c|c|c|}
\hline \multirow{2}{*}{ Water system } & \multicolumn{3}{|c|}{$\mathrm{Zn}(\mu \mathrm{g} / \mathrm{L})$} & \multicolumn{3}{c|}{$\mathrm{Pb}(\mu \mathrm{g} / \mathrm{L})$} & \multicolumn{3}{c|}{$\mathrm{Cd}(\mu \mathrm{g} / \mathrm{L})$} \\
\cline { 2 - 11 } & 2015 & 2016 & 2017 & 2015 & 2016 & 2017 & 2015 & 2016 & 2017 \\
\hline $\begin{array}{c}\text { Main } \\
\text { drainage } \\
\text { channel }\end{array}$ & 15.2 & 12.7 & 11.6 & $<1.0$ & $<1.0$ & $<1.0$ & 0.25 & 0.18 & 0.21 \\
\hline $\begin{array}{c}\text { Rating for } \\
\text { each } \\
\text { indicator }\end{array}$ & I & I & I & I or II & I or II & I or II & II & II & II \\
\hline River Lonja & 22.1 & 10.5 & 10.8 & $<1.0$ & $<1.0$ & $<1.0$ & 0.23 & 0.20 & 0.35 \\
\hline $\begin{array}{c}\text { Rating for } \\
\text { each } \\
\text { indicator }\end{array}$ & I & I & I & I or II & I or II & I or II & II & II & II \\
\hline River Sava & 22.9 & 18.4 & 14.2 & $<1.0$ & $<1.0$ & $<1.0$ & 0.19 & 0.23 & 0.27 \\
\hline $\begin{array}{c}\text { Rating for } \\
\text { each } \\
\text { indicator }\end{array}$ & I & I & I & I or II & I or II & I or II & II & II & II \\
\hline
\end{tabular}

\section{Organic matter}

Data on the dissolved organic carbon, DOC and surface active substances, SAS are presented in Table 5.

Table 5: Concentrations of DOC and SAS

\begin{tabular}{|l|l|l|}
\hline Water system & $\begin{array}{l}\text { DOC } \\
\mathrm{mg} \mathrm{C} \mathrm{dm}^{-3}\end{array}$ & $\begin{array}{l}\text { SAS } \\
\mathrm{mg} \mathrm{dm}^{-3} \text { eq. Triton-X-100 }\end{array}$ \\
\hline Main drainage channel & $9.48-13.35$ & $0.195-0.197$ \\
\hline River Lonja & $4.62-7.75$ & $0.209-0.211$ \\
\hline \multirow{2}{*}{ River Sava } & 1.60 & 0.200 \\
& $1.57-3.30^{*}$ & $0.017-0.620^{*}$ \\
\hline
\end{tabular}

*Orlović-Leko et al., 2004. 
Concentration of DOC in the main water channel were in the range of 9.48 to $13.35 \mathrm{mg} \mathrm{C} \mathrm{dm}^{-3}$ (Table 5). These DOC concentrations are significant higher (2 to 8 times) than those measured in the surface freshwater systems of the rivers Lonja and Sava. In comparison, concentrations of DOC in the drainage water of hydroameliorated agricultural areas in the central Sava river valley, Croatia, were in the range from 1.07 do $9.93 \mathrm{mg} \mathrm{C} \mathrm{dm}^{-3}$ (Orlović-Leko et al., 2016). Concentrations of DOC in natural fresh waters range from $\sim 1$ to $60 \mathrm{mg} \mathrm{C} \mathrm{dm}^{-3}$, but are commonly from 1-5 mg C dm${ }^{-3}$ (McDonald et al., 2004).

Table 6: The ratio SAS/DOC values obtained in investigated water samples and in different model substances (Ćosović et al., 2007; Orlović et al, 2016)

\begin{tabular}{|c|c|c|}
\hline SAS & $\begin{array}{c}\text { SAS eq T-X-100/ } \\
\text { DOC }\end{array}$ & $\begin{array}{c}\text { Dominant SAS in the } \\
\text { water samples }\end{array}$ \\
\hline Triton-X-100 & 1.54 & \\
\hline Lignosulphonate & $6,8 \times 10^{-4}$ & \\
\hline Monocarboxylic acids & & \\
\hline Caprylic acid (pH=4) & 0.016 & \\
\hline Capric acid (pH=4) & 0.17 & \\
\hline Capric acid (pH=6.5) & 0.015 & \\
\hline Oleic acid & 2.7 & \\
\hline 3-Hydroxybutanoic acid & 0.05 & \\
\hline 3-Hydroxybenzoic acid & $8.2 \times 10^{-4}$ & \\
\hline cis-Pinonic acid & 0.001 & \\
\hline Polycarboxylic acids & & \\
\hline Humic acid & 0.04 & \\
\hline Fulvic acid & 0.17 & Monocarboxylic acids \\
\hline Protein & & \\
\hline Albumine & 0,20 & Fulvic acid \\
\hline Polysaccharide & & \\
\hline Xanhtan & 0.04 & \\
\hline Water samples in this work & & \\
\hline Main drainage channel & 0.017 & \\
\hline River Lonja & 0.03 & \\
\hline River Sava & 0.16 & \\
\hline
\end{tabular}

A quantification of adsorbable organic substances was performed by using a calibration plot of Triton-X-100 (Ćosović and Vojvodić, 1998; Orlović-Leko et al., 2016). The relative concentrations of surface active substances (SAS) for all investigated water samples were relatively low (Table 5). The relative concentrations of SAS values obtained in the drainage water samples were between 0.11 and $0.45 \mathrm{mg} \mathrm{dm}^{-3}$ eq. Triton-X-100, with the average value of 0.36 
$\pm 0.10 \mathrm{mg} \mathrm{dm}^{-3}$ (Orlović-Leko et al., 2016). However, the concentration of SAS also depends on the nature of the organic molecules in the samples.

The rapid and rough SAS characterization in the studied samples was done by comparisson of its SAS/DOC ratio values with SAS/DOC ratios of different model substances, possible constituents and/or pollutants in aquatic system (Table 6). Triton X-100, here presented as a model of strongly adsorbable surfactant, it is reasonable to expect that very small amounts of some strongly adsorbable substances, for example pollutants, could markedly increase surfactant activity of water samples (Orlović-Leko, 2004).

As can be seen from Table 6, SAS in the main drainage channel water were with similar adsorption behaviour like monocarboxylic acids, while in the river Lonja, SAS/DOC $=0.03$ and are very close to the ones determined for xanhtan and humic acid. Further, from the result for Sava river $(\mathrm{SAS} / \mathrm{DOC}=$ 0.16 ) can be concluded that fulvic acid represent a predominant class of surface active material. Generaly, in the freshwater samples humic and fulvic acid main class of surface active material, mainly from terrestrial input (Orlović-Leko et al., 2016). The presence of the monocarboxylic acids in the main drainage channel can be probable consequence proceses of the decomposition of complex organic material.

\section{CONCLUSION}

On the basis of the indicators for determining water quality in the main drainage channel and rivers of Lonja and Sava, the following can be concluded that the impact of the use of hydromeliorated agricultural land for cultivation of agricultural crops on the surface water quality has been established for nutrient which is obviously a consequence of mineral fertilization and organic matter.

\section{ACKNOWLEDGMENTS}

This work is supported by the projects "The Sulphur and Carbon Dynamics in the Sea and Fresh-Water Environment" (IP-11-2013-1205 SPHERE) and "Financings of scientific activity (No. 1-14-900)-University of Zagreb.

\section{REFERENCES}

Ayers, R., Westcot, D.W. (1985) Water quality for agriculture. FAO Irrigation and Drainage paper. Food and agriculture organization of the United nations, No.29, Roma.

Cukrov, N., Cmuk, P., Mlakar, M., Omanovic, D. (2008) Spatial distribution of trace metals in the Krka River, Croatia: An example of the self-purification. Chemosphere, 72; 15591566.

Ćosović B, Vojvodić V. (1998) Voltammetric analysis of surface active substances in natural seawater. Electroanalysis, 10; 429-434.

Ćosović B., Orlović-Leko, P., Kozarac, Z. (2007) Rainwater Dissolved Organic Carbon: Characterization of Surface Active Substances by Electrochemical Method. Electroanalysis, 19-20; 2077-2084.

Čoga, L., Vidaček, Ž., Poljak, M., Kovačević, V. (1998) Cadmium and lead in the system drained soil-plant-water in the Drava-Danube catchment area. 16thWorld Congress of Soil Science, 1;13 (Summary), Montpellier, August 20-26.

Đumija, LJ., Manitašević, J. (1989) Determination of heavy metals and inorganic pollutants in water of canals on experimental field Ježevo. Agrohemija, 1-3; 69-77. 
Filella, M. (2009) Freshwaters: which NOM matters. Environmental Chemistry Letters, 7; 2135.

Jakovčić,T., Marijanović Rajčić, M., Senta, A. (2003) Assessment of Anthropogenic Influence on Pollution of River Water Drava and Mura by Heavy Metals. Proceedings- 3th Croatian Conference on Waters. 291-294. Osijek, May 28-31.

Josipović, M., Kovačević, V., Šoštarić, J., Plavšić, H., J. Liović. (2006) Influences of irrigation and fertilization on soybean properties and nitrogen leaching. Cereal Research Communications, 34 (1); 513-516.

Matson, P.A., Parton, W.J., Power, A.G., Swift, M.J. (1997) Agricultural intensification and ecosystem properties. Science, 277; 504-509.

McDonald, S., Bishop, A.G., Prenzler, P.D., Robards, K. (2004) Analytical chemistry of freshwater humic substances. Analytica Chimica Acta 527, 2; 105-124.

Mesić, M., Bašić, F., Kisić, I., Butorac, A., Gašpar, I. (2007): Influence of mineral nitrogen fertilization on corn grain yield and nitrogen leaching. Cereal Research Communications 35 (2); 773-776.

Moore, J.W. (1981): Influence of water movements and other factors on distribution and transport heavy metals in a shallow bay (Canada). Arch Environ Contam Toxicol, 10; 7-15.

Nemčić, J.J., Mesić, M., Bašić, F., Kisić, I., Zgorelec, Z. (2007) Nitrate concentration in drinking water from wells at three different locations in Northwest Croatia. Cereal Research Communication, 35 (2); 533-536.

Nemeth, T. (2006) Nitrogen in the soil-plant system nitrogen balances. Cereal Research Communications, 34 (1); 61-64.

Orlović-Leko, P., Kozarac, Z., Ćosović, B. (2004) Surface active substances (SAS) and dissolved organic matter (DOC) in atmospheric precipitation of urban area of Croatia (Zagreb). Water Air and Soil Pollution, 158; 295-310.

Orlović-leko, P., Vidović, K., Plavšić, M., Ciglenečki, I., Šimunić, I., Minkina, T. (2016) Voltammetry as a tool for rough and rapid characterization of dissolved organic matter in the drainage water of hydroameliorated agricultural areas in Croatia. Journal of Solid State Electrochemistry, 20; 3097-3105.

Pratt, P., Jury, W.A. (1984) Pollution of the unsaturated zone with nitrate. Ecological Stududies, 47; 52-67.

Rademacher, J.J., Young, T.B., Kanarek, M.S. (1992) Gastric cancer mortality and nitrate levels in Wisconsin drinking water. Archives of Environmental Health, 47; 292-294.

Šimunić, I., Tomić, F., Kisić, I., Romić, M. (2002) The content of $\mathrm{Pb}, \mathrm{Zn}$ and $\mathrm{Cd}$ in hydroameliorated soil and drainage water and their uptake by plants. Rostlina vỳroba, 48 (9); 401-406.

Šimunić, I., Mesić, M., Sraka, M., Likso, T., Čoga, L. (2011) Influence of drainage on nitrate leaching and maize yield. Cereal Research Communications, 39 (2); 273-282.

Šimunić, I. (2016) Water quality. In book: Regulation and protection of water. Croatian University Press, Zagreb, 165 p.

Vidaček, Z., Sraka, M., Čoga, L., Mihalić, A. (1999) Nitrates, heavy metals and herbicides in soil and water of Karasica-Vucica catchment area. Agriculturae Conspectus Scientificus, 64 (2); 143-150.

Tchounwou, P.B., Yedjou, C.G., Patlolla, A.K., Sutton, D.J.(2012): Heavy Metals Toxicity and the Environment. Experientia Supplementum, 101; 133-164.

Wong, S.C., LI, X., Thornton, I. (2006) Urban enviromental geochemistry of trace metals. Enviromental Pollution, 142; 1-16.

Water Framework Directive (Directive 2000/60/EC)

Official Gazette of the Republic of Croatia - Water Classification Decree (National Gazette, 137/08). 